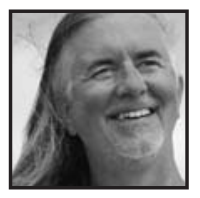

\title{
The Curriculum of Desire: Four Poems
}

\section{Carl Leggo, University of British Columbia}

\section{Lost and Found}

\section{(Press Here for Sound)}

always wanted to be a saint, perhaps St. Francis of Assisi.

But somewhere along the long way to middle age, I lost my way, at least my conscience (learned I am no more a saint than Roger Moore or a St. Bernard).

Nobody has turned my conscience in at the Lost and Found, even though, like false teeth, it's no good to anyone else.
All I know is I once had a conscience, but lost it. I'm not sure when or where.

One day it was gone, like losing hair, heart, teeth, smooth skin, elasticity in underwear.

Now I confess I have only a few thin proverbs to guide me, like combing sparse wet hairs over a shiny skull. 


\section{What I Want}

(Press Here for Sound)

$\mathrm{n}$ the cusp of old age I no longer

want to argue about the lack

of soap in the shower and whose

responsibility it was to replace

the fragile wafer, so many

details like armies of mites.

Instead I want to remember

the pineapple juice with psyllium

I sipped in this slow motion morning

and the organic banana I forgot to eat

and The Vancouver Sun I didn't read

while I stared out the kitchen window

at the parade of men in denim overalls, men, like my father, I will never know, who ambled to the noisy warehouse where they shuffle with acetylene torches all day amidst clanging iron composing the alchemic syntax of girders and trusses

while Mr. Burns sleeps in the patio door steeped in the late winter sunlight filled with hope for an early treat, a long day's sleep, and dinner that can never come fast enough, but will come, he is sure. 


\section{Diaspora}

(Press Here for Sound)

have seen sea gulls far from the sea at KFC in Fredericton, keen as giggling adolescents for deep-fried chicken

I have seen sea gulls far from the sea in Sault St. Marie, scavenging for sprinkled Timbits at Tim Horton's

I have seen sea gulls far from the sea like hoarfrost in wind-tossed fields of Saskatchewan canola and flax and I have seen sea gulls suspended in Atlantic gusts between sea and sky like bleached rags blowing in the wind or white flags calling a weary truce: I too have explored ample possibilities for returning, if possible, to the sea 


\section{Alex Faulkner}

(Press Here for Sound)

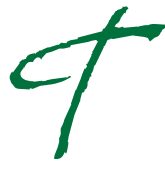

he first Newfoundlander to play in the $\mathrm{NHL}$ was Alex Faulkner, and one time I stood in line, a long time, outside the CBC in Corner Brook, for his autograph, sure the Detroit Red Wings were the greatest hockey team that ever played, and when I told Nicholas how great Faulkner was, he nodded politely

then last summer while bussing across Newfoundland from one coast to another, Nicholas read The Central Newfoundland Tourist Guide, and learned what happens to hockey greats, slipped me a folded scrap of paper, an advert for the Beothuck Family \& RV Park:

A Great Quite Family oriented Park to Relax Owned and Operated by Alex Faulkner The First Newfoundland NHL Player 6 foot water slideRV Dumping Station

(no punctuation between slide and RV Dumping, only the image of sliding 6 feet into what RV's dumped)

and while I flinched with a stab for extinct Beothuck families who will never relax in Faulkner's park, my first thought was the predictable punctilious response of an old English teacher: Alex needs a better editor

the grasshopper jumped, bumped into my leg, tumbled head over heels, somersaults like a Cirque du Soleil artist, perhaps just for the fun of it 
now we have all gathered in the hospital where Pop is on a ventilator, propped up, in forest green pajamas with a maroon trim like Hugh Hefner wears, glad he is still alive, surprising himself and all of us

Sterling just dropped in, and Pop tells him how Joe Gullage's bed was wheeled away to palliative care an hour ago, and now ten of us huddle around Pop's bed like angels who can't find our flaming swords and everybody talks at the same time, even if nobody can hear anybody, even if we've long run out of things to say

and when Cliff asks Pop how he is, Pop holds up the oxygen line, I'm tied on too short

and the nursing assistants and doctors with their clipboards come and go as if rehearsing for guest spots on $E R$ and none of us knows, so we make up scenarios stewed in familiar TV fictions

the grasshopper

jumped, bumped

into my leg, tumbled

head over heels, somersaults

like a Cirque du Soleil artist,

perhaps just for the fun of it

Michael Crummey's new novel The Wreckage lies on the window ledge

as I watch people in the parking lot, far below, I ask Nicholas, Do you think this is what God sees when he looks down at us scurrying here and there 
but Nicholas growls, Don't make me come down there, and I like that line, a lot, and according to Picasso cited on a stamp in my moleskin journal like Hemingway wrote in (according to the sign in the Nikaido shop in Steveston):

There's nothing more difficult than a line

and I determine I will commit whatever life I have left to body-building and joy and writing zigzags

in the sharp brokenness all around me

the grasshopper

jumped, bumped

into my leg, tumbled

head over heels, somersaults

like a Cirque du Soleil artist,

perhaps just for the fun of it

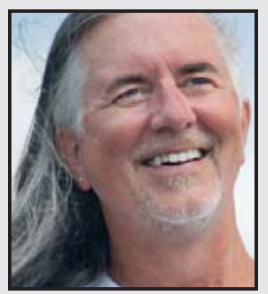

Carl Leggo is a poet and professor in the Department of Language and Literacy Education at the University of British Columbia. His poetry, fiction and essays have been published in many journals. He is the author of several books including: Growing Up Perpendicular on the Side of a Hill, View from My Mother's House, Come-By-Chance, Teaching to Wonder: Responding to Poetry in the Secondary Classroom, and Lifewriting as Literary Metissage and an Ethos for Our Times (with Erika Hasebe-Ludt and Cynthia Chambers). Also, he is a coeditor of Being with A/r/tography (with Stephanie Springgay, Rita L. Irwin, and Peter Gouzouasis), and of Creative Expression, Creative Education (with Robert Kelly).

\section{LINKTO:}

http://led.educ.ubc.ca/faculty/leggo.htm 